\title{
Critique of "Racial Discrimination in 'Private' Housing"
}

\author{
Francis A. Allen*
}

A MERICAN SOCIETY has rarely been confronted by issues so fundamental the most profound results of the civil rights movement is its impact on American constitutional law. One may say without exaggeration that American constitutional law is beset by a crisis of theory. No doubt there are many, including many lawyers and judges, who are disposed to award a rather low priority to the integrity of legal theory, in contrast to the attaining of desired social and political objectives. Yet this lack of concern for the requirements of theory strikes at the very legitimacy of the judicial function in constitutional cases. For, if the judicial process is not a process of reason, if there are not significant differences in judicial and legislative law-making, what claim can the institution of judicial review make on a nation whose institutions reflect strong democratic tendencies?

For these reasons, any conscientious effort to discipline an unruly area of constitutional doctrine deserves respectful consideration. This is especially true when the effort, like that made im Mr. Horowitz's illuminating paper, produces genuine insights and valuable aids to thinking about difficult and important problems. Limitations of time and space preclude attention to more than a few general aspects of the argument. No consideration can be given to the range of his suggestions. Even those aspects selected for discussion will be summarily and, perhaps, cryptically treated.

Fundamental to Mr. Horowitz's analysis is his conception of "state action" in fourteenth amendment adjudication. "The thesis advanced," he writes, "is that in the federal system those legal relationships between private persons which do not have their source in federal law are created by state law, and are the product of state action in a fourteenth amendment sense." I In short, as I understand the argument, when the state permits it acts, and acts as fully im the constitutional sense as when it directs or forbids. It does not follow, of course, that all "private" discriminations permitted by state law violate the amendment. But if not, this is because of other considerations which, in Mr. Horowitz's view, should not be confused with the issue of state action.

For the moment I shall not deal with the proposition in its full gen-

* Professor of Law, University of Chicago Law School.

1 Horowitz, Fourteenth Amendment Aspects of Racial Discrimination in "Private" Housing, 52 CArIF. L. REv. 1, 22 (1964). 
erality. Instead, I shall first assert that there are some modern fourteenth amendment decisions that can be explained honestly only by reference to the premise that situations exist in which the states are under constitutional compulsion to prevent discrimination by private persons or groups. The best illustrations of this observation are perhaps the "white primary" cases-Smith v. Allwright ${ }^{2}$ and, more particularly, Terry v. Adams. ${ }^{3}$ This is not a proper occasion for an extended analysis of these decisions. I shall simply say that the assault on the prevailing opinions contained in Professor Wechsler's well-known essay is, for me, wholly persuasive. ${ }^{4}$ It is not enough, however, to say that the white primary cases were badly reasoned, that the opinions were unprincipled, or even that they were wrongly decided. The fact is that the results of those cases represent precedents about as durable as any that can be pointed to in the law of the fourteenth amendment.

How are these results to be articulated? The only explanation that appears adequate is the one suggested: the states are under constitutional obligation to prevent private groups from denying large numbers of citizens effective participation in the political life of the communty. Mr. Horowitz presents evidence to suggest that this proposition is consistent with the expectations of at least some persons who had something to do with the drafting of the amendment. ${ }^{5}$

Mr. Horowitz defends an even broader proposition. His argument is that not only are there particular situations in which the failure of the state to supply sanctions and remedies against discrimination by private groups satisfies the state action requirement, but that state action in the constitutional sense occurs in all cases in which the state has permitted private persons to discriminate. I shall only say that I doubt this suggestion makes as significant a contribution to clear analysis as Mr. Horowitz seems to assume. Clearly, the proposition is not that all pernnitted discriminations violate the fourteenth amendment. The ultimate decision requires consideration of a range of circumstances, among which are the kind and nature of state participation and action. Thus for Mr. Horowitz it clearly may make a difference whether the state has compelled the discrimination, as in Shelley $v$. Kraemer, ${ }^{6}$ or whether it has merely tolerated the discrimination. ${ }^{7}$ Are the problems rendered significantly more amenable to intelligent consideration if the question is: "In the given situation, is this the kind of state action that violates the amendment?" rather

\footnotetext{
2321 U.S. 649 (1944).

3345 U.S. 461 (1953).

4 Wechsler, Toward Neutral Principles of Constitutional Law, 73 HARv. L. REv. 1 (1959).

- Horowitz, supra note 1, at 25 n.65.

6334 U.S. 1 (1948).

7 Horowitz, supra note 1 , at 45 .
} 
than "In the given circumstances, does the tolerance of discrimination amount to state action in the constitutional sense?"

However this may be, Mr. Horowitz's proposition advances a premise quite different from that traditionally expressed in fourteenth amendment adjudication; and his effort to establish that "no departure" from the older cases is involved in its acceptance seems particularly unpersuasive. It is true that the Civil Rights Cases $^{8}$ concerned congressional legislation not limited in its application to situations in which the states had failed to provide sanctions against the "private" discriminations in question. Indeed, the 1875 Act clearly contemplated the existence of similar state legislation; section 2, in effect, required litigants to elect between the state and the federal reinedy. ${ }^{9}$ One may, I suppose, read Mr. Justice Bradley's opinion in such a way as to inake this circumstance crucial. But given the character of the opinion and the role it has played in our constitutional history, I see no reason or justification for doing so. The fourteenth amendment, says Justice Bradley, does not grant to Congress power "to establish a code of municipal law." 10 "It is absurd to affirm . . . that, because the denial by a State to any persons, of the equal protection of the laws, is prohibited by the amendment, therefore Congress may establish laws for their equal protection."11 To be sure, the opinion notes that the congressional statute is not rendered inapplicable by the presence of state laws protecting the rights asserted. It also notes that the statute makes no "reference to adverse State Legislation on the subject." ${ }^{12}$ It may be conceded that Mr. Horowitz's reading of the Civil Rights Cases does not reject the major premise of Justice Bradley's opinion. But the argument does violence to the ininor premise. Manipulations of the minor premise constitute the familiar technique of courts engaged in effecting changes and development in legal doctrine. I do not condemn the process or deny its importance, particularly in the areas under consideration. I simply suggest that commentators, at least, can afford the luxury of candor.

Mr. Horowitz's treatment of sone of the other cases might also be criticized. I shall not submit a full catalogue of ny grievances. One or two illustrations will suffice. It seems clear to ine that Shelley v. Kraemer more nearly offends traditional concepts, not when it argues that voluntary adherence to the agreements "standing alone" does not constitute state action, but when it holds that enforceinent of the agreement does. ${ }^{13}$ It seems to ne, also, that early in his paper Mr. Horowitz may not have italicized enough of his excerpt from Marsh $v$. Alabama. ${ }^{14}$ Perhaps it is

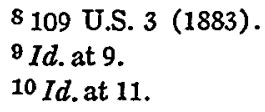

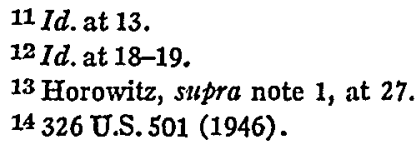


not the word "permitting" but the phrase "permitting a corporation to govern a community" that is significant. ${ }^{15}$

Mr. Horowitz's paper suggests another point of some importance, to which brief attention will be given in conclusion. As fourteenth amendment law expands and mcreasingly impinges upon areas formerly thought to be wholly of private concern, consideration must be given to the distinction between the amendment as a source of judicial power and as a source of legislative authority. The importance of this distinction is perhaps greater in areas like housing than in many others. Assuming arguendo that the amendment has something to say about discriminations by property owners whose relations to and benefits from the state are not different from property owners generally, the questions posed seem often inappropriate for judicial resolution. Mr. Horowitz suggests that various factors may be relevant to the consideration of these problems. The general state of the housing market in the locality is said to be one of these. ${ }^{16}$ The kinds of property involved may also make a difference. A single-family dwelling raises questions different from the apartment house. The small apartinent house, in turn, may be distinguished from a large apartment development. ${ }^{17}$ There is surely reason to doubt that such questions can be resolved through the processes of principled adjudication. That these questions are not more difficult or less congenial to the exercise of judicial power than many of the imponderables unearthed by Baker v. Carr ${ }^{18}$ strengthens, in my view, rather than weakens the observation. If we are committed to resolving these problems by the force of law, and if the questions defy principled resolution, the alternative to judicial decision-making provided by a free society is resort to the legislative process. These questions will be resolved, if at all, through a vectoring of the power of concerned groups. Surely, the legislature, rather than the courts, is the proper arena for hammering out such accommodations. Exercise of state legislative power for these purposes presents no substantial constitutional problems of which I am aware. If, however, resort is to be made to the legislative power of Congress, particularly that conferred by the fifth section of the fourteenth amendment, a new range of questions for constitutional theory is raised. Apart from the usual judicial deference paid judgnients on the limits of congressional power by a coordinate branch of the government, does the fifth section create a repository of power going beyond that possessed by the court acting in the absence of a federal statute? If so, what principles can be suggested to delineate the scope of such authority? I, for one, should be interested in having the advantage of Mr. Horowitz's thoughts on these matters.

15 Horowitz, supra note 1, at 9.

16 Id. at $28-29$.
17 Id. at 31 .

18369 U.S. 186 (1962). 